\title{
Evaluation of storage stability of soybean biodiesel using a flame ionization detector coupled to a gas chromatography system
}

\author{
Mozart D Bispo', Flávia Manuella R de Mendonça1*, Jamilly AS Barros², Cláudio Dariva, Laiza C Krause \\ From 5th Congress of the Brazilian Biotechnology Society (SBBIOTEC) \\ Florianópolis, Brazil. 10-14 November 2013
}

\section{Background}

Biodiesel, an alternative energy source, has been attracting increasing worldwide interest in recent decades. It is obtained by base-catalyzed transesterification, resulting in a final mixture consisting of mono-alkyl esters and other by-products (e.g. glycerol, alcohol, free fatty acids). This composition provides a level of operational quality control that enables biodiesel to be marketed efficiently, because its viability depends on several factors, such as stability during the storage period. Unlike fossil fuels, which are relatively inert and therefore undergo few alterations to their properties during storage, biodiesel degrades through oxidation and hydrolysis, with consequent alterations to its properties, due to exposure to the environment. Thus, the purpose of this study was to monitor soybean biodiesel quality using a flame ionization detector (FID) coupled to a gas chromatography (GC) system.

\section{Methods}

In the alkali catalytic methanol transesterification method, the catalyst $(\mathrm{KOH})$ is dissolved in methanol by vigorous stirring in a small reactor. The oil is transferred into the biodiesel reactor, and then, the catalyst/alcohol mixture is pumped into the oil. A successful transesterification reaction produces two liquid phases: ester and crude glycerin. Crude glycerin, the heavier liquid, will collect at the bottom after several hours of settling. Phase separation can be observed within $10 \mathrm{~min}$ and can be complete within 2 $\mathrm{h}$ of settling. Soybean biodiesel samples were stored for 7 , 15 and 30 days at two different temperatures (room temperature and $8^{\circ} \mathrm{C}$ ). GC-FID was used as single methodology to evaluate the ester content and storage stability of

${ }^{1}$ Pós-Graduação em Biotecnologia Industrial, Universidade Tiradentes, Aracaju, SE, Brazil

Full list of author information is available at the end of the article the samples in the following manner: a DB-Waxetr capillary column $(30 \mathrm{~m} \times 0.25 \mathrm{~mm}, 0.25 \mu \mathrm{m})$, injection volume of $1 \mu \mathrm{L}$, and $\mathrm{N}_{2}$ as carrier gas. The column temperature was maintained at $170^{\circ} \mathrm{C}$ for $1 \mathrm{~min}$, and then ramped up at $10^{\circ} \mathrm{Cmin}^{-1}$ to $210^{\circ} \mathrm{C}$, kept at $210^{\circ} \mathrm{C}$ for $1 \mathrm{~min}$, then ramped up at $5^{\circ} \mathrm{Cmin}^{-1}$ to $230^{\circ} \mathrm{C}$, and kept at $230^{\circ} \mathrm{C}$ for $6 \mathrm{~min}$. These samples were then compared to standard compounds. The FID temperature was $230^{\circ} \mathrm{C}$.

\section{Results and conclusion}

The GC-FID analysis showed results that allowed biodiesel esters to be identified and quantified, indicating biodiesel degradation during storage periods, a decrease in ester content of $14.40 \%$ and $16.0 \%$ at $8^{\circ} \mathrm{C}$ and room temperature, respectively. The GC-FID method is especially suitable as a rapid tool for control purposes in order to determine the methyl ester content quickly, simply and inexpensively, in order to meet Brazil's National Agency of Petroleum, Natural Gas and Biofuels (ANP) requirements for biodiesel commercialization.

\section{Acknowledgements \\ Authors would like to express their gratitude to CNPq, UNIT, CAPES and} FAPITEC for the financial support and scholarships

\section{Authors' details}

'Pós-Graduação em Biotecnologia Industrial, Universidade Tiradentes,

Aracaju, SE, Brazil. ${ }^{2}$ Curso de Farmácia, Universidade Tiradentes, Aracaju, SE, Brazil. ${ }^{3}$ Pós-Graduação em Engenharia de Processos, Universidade Tiradentes, Aracaju, SE, Brazil.

\section{Published: 1 October 2014}

\section{References}

1. Fernandes DM, Montes $\mathrm{RHO}$, Almeida ES, Nascimento AN, Oliveira PV, Richter EM, Muñoz RAA: Storage stability and corrosive character of stabilised biodiesel exposed to carbon and galvanised steels. Fuel 2013, 107:609-614. 
2. Kumar N, Chauhan SR: Performance and emission characteristics of biodiesel from different origins: a review. Renewable and Sustainable Energy Reviews 2013, 21:633-658.

3. Leung DYC, Koo BCP, Guo Y: Degradation of biodiesel under different storage conditions. Bioresource Technology 2006, 97(2):250-256.

4. Mofijur M, Masjuki HH, Kalam MA, Atabani AE, Shahabuddin M, Palash SM, Hazrat MA: Effect of biodiesel from various feedstocks on combustion characteristics, engine durability and materials compatibility: A review. Renewable and Sustainable Energy Reviews 2013, 28:441-455.

doi:10.1186/1753-6561-8-S4-P210

Cite this article as: Bispo et al:: Evaluation of storage stability of

soybean biodiesel using a flame ionization detector coupled to a gas chromatography system. BMC Proceedings 2014 8(Suppl 4):P210.

\section{Submit your next manuscript to BioMed Central} and take full advantage of:

- Convenient online submission

- Thorough peer review

- No space constraints or color figure charges

- Immediate publication on acceptance

- Inclusion in PubMed, CAS, Scopus and Google Scholar

- Research which is freely available for redistribution

Submit your manuscript at www.biomedcentral.com/submit
C Biomed Central 